\title{
Auditory Middle Latency Response and Phonological Awareness in Students with Learning Disabilities
}

\author{
Ana Carla Leite Romero ${ }^{1}$ Carolina Araújo Rodrigues Funayama ${ }^{2}$ Simone Aparecida Capellini ${ }^{1}$ \\ Ana Claudia Figueiredo Frizzo ${ }^{1}$
}

${ }^{1}$ Department of Speech Therapy, Unesp, Sergipe, Marília, São Paulo, Brazil

${ }^{2}$ Department of Otorhinolaringology, Usp, Ribeirão, Preto, Brazil

Address for correspondence Ana Carla Leite Romero, MSc, Department of Fonoaudiologia, Unesp, Marília-SP Sergipe, 814 Sergipe, 814 Marília, São Paulo 17515100, Brazil (e-mail: anacarla_Ir123@hotmail.com).

Int Arch Otorhinolaryngol 2015;19:325-330.

\begin{abstract}
Introduction Behavioral tests of auditory processing have been applied in schools and highlight the association between phonological awareness abilities and auditory processing, confirming that low performance on phonological awareness tests may be due to low performance on auditory processing tests.

Objective To characterize the auditory middle latency response and the phonological awareness tests and to investigate correlations between responses in a group of children with learning disorders.

Methods The study included 25 students with learning disabilities. Phonological awareness and auditory middle latency response were tested with electrodes placed on the left and right hemispheres. The correlation between the measurements was performed using the Spearman rank correlation coefficient.

Keywords

- learning disability

- hearing

- evoked potentials auditory

- cognition

- learning

Results There is some correlation between the tests, especially between the $\mathrm{Pa}$ component and syllabic awareness, where moderate negative correlation is observed. Conclusion In this study, when phonological awareness subtests were performed, specifically phonemic awareness, the students showed a low score for the age group, although for the objective examination, prolonged Pa latency in the contralateral via was observed. Negative weak to moderate correlation for Pa wave latency was observed, as was positive weak correlation for Na-Pa amplitude.
\end{abstract}

\section{Introduction}

The initial process of reading and writing acquisition is directly related to phonological awareness ability (i.e., the ability to recognize, decompose, compose, and manipulate speech sounds). ${ }^{1-3}$ Phonological awareness is the ability to understand that words are made up of smaller components that can be separated and manipulated. It is the ability to analyze speech in its phonological components and their combinations based on acoustic recognition., ${ }^{4,5}$

received

February 10, 2015

accepted

March 25, 2015

published online

May 27, 2015
The proper development of phonological awareness is vital for the child to correlate the aspects of speech sounds with the writing code by converting phoneme to grapheme, properly developing the foundations of reading and writing. ${ }^{6}$ Studies show that students with learning disabilities present impairments in cognitive, linguistic, visual processing, and auditory information processing. When the activation of cognitive mechanisms to analyze, synthesize, manipulate, store, and recall linguistic information is altered, impairments in phonological awareness and phonological working memory

Copyright $\odot 2015$ by Thieme Publicações License terms Ltda, Rio de Janeiro, Brazil

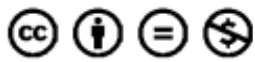


Romero et al.

occur, causing difficulties in the perception and production of speech whether orally or in reading. ${ }^{7,8}$

In Brazil, behavioral tests of auditory processing are applied in schools and highlight the association between phonological awareness abilities and auditory processing, confirming that low performance on phonological awareness tests may be due to low performance on auditory processing tests. $^{7-9}$ In addition to behavioral tests to assess hearing, the auditory middle latency auditory response (AMLR), ${ }^{10,11}$ an objective test for assessing central auditory system, has also been employed in children with learning disorders. Several studies have demonstrated the diagnostic value of this potential to assess the injuries of central auditory nervous system (CANS); however, little is known about the value of AMLR diagnosis for cases of auditory processing disorder and its effectiveness to investigate the occurrence of CANS impairments. Auditory evoked response also has advantages over behavioral tests, as it helps in differentiating expressive or receptive problems. ${ }^{12}$

Studies reported that AMLR in students with learning disorders show typical wave morphologies, such as elongated latency for $\mathrm{Na}$ wave and decreased amplitude for $\mathrm{Nb}$ wave, consistent with perceptual difficulty at the cortex level. ${ }^{12,13}$ Currently, research describing AMLR and phonological awareness in students with learning disorders analyze the tests separately ${ }^{14,15}$; therefore, the literature does not describe any studies directly associating phonological awareness and AMLR, evidencing the need to invest in scientific research in this field.

Based on these points, this study aimed to characterize the AMLR potentials and the phonological awareness tests and to investigate correlations between responses in a group of students with learning disorders.

\section{Methods}

This study was conducted after the institution's Ethics Committee reviewed and approved it under submission number $1512 / 2007$, case number $118 / 2007$, after subjects signed the informed consent. This research is characterized as an observational, cross-sectional, nonrandomized study.

The investigation included 25 children of both sexes (14 boys and 11 girls) with learning disorders; $72 \%$ were between 8 and 10 years of age ( - Table 1 ), and average age was 9 years and 9 months. The children were enrolled in the third grade of elementary school.

The participants were volunteers from a learning disorders clinic. They showed no medical history of chronic diseases, epilepsy, motor developmental disorders, motor or sensory impairment disorder, attention deficit hyperactivity disorder, or autism spectrum disorder.

The diagnosis of learning disorders was considered when, during assessment by the multidisciplinary team (neurologist, neuropsychologist, and speech-language pathologist) of the students' institution, any of the following was found: discrepancy between verbal IQ and performance in psychological assessment; Wechsler Intelligence Scale for ChildrenIII $^{16}$ changes in the memory, reading, and writing in the
Table 1 Distribution of participants by age group

\begin{tabular}{|l|l|l|}
\hline Age (y) & $\boldsymbol{n}$ & $\%$ \\
\hline 8 & 7 & 28 \\
\hline 9 & 5 & 20 \\
\hline 10 & 6 & 24 \\
\hline 11 & 2 & 8 \\
\hline 12 & 2 & 8 \\
\hline 13 & 1 & 4 \\
\hline 14 & 2 & 8 \\
\hline Total & 25 & 100 \\
\hline
\end{tabular}

neuropsychological tests ${ }^{17}$; difficulty in oral reading and writing under dictation of words and pseudowords; phonological disorders in speech and writing; changes in syllabic and phonemic skills in phonological awareness tests ${ }^{18}$; significant changes in syntactic and semantic language skills and in other areas of learning such as mathematical reasoning. ${ }^{19}$

All participants in this study were submitted to the Phonological Awareness Test: Instrumento de Avaliação Sequential-CONFIAS (phonological awareness sequential evaluation instrumentl), ${ }^{20}$ which is composed of two parts. The first part of the test corresponds to syllabic awareness and consists of nine items: synthesis, segmentation, identification of initial syllable, rhyme identification, production of a word with a given syllable, identification of medial syllable, rhyme production, exclusion, and transposition. The second part of the test corresponds to phoneme awareness and consists of seven items: production of a word that begins with the given sound, identification of initial phoneme, identification of the final phoneme, exclusion, synthesis, segmentation, and transposition. The test was scored in a specific protocol. Each correct answer given by the student is scored 1 point and each incorrect answer is scored 0 points. The highest possible score is 70 (syllabic tasks $=40$ points and phonemic tasks $=30$ points).

The evaluations were conducted individually, in a silent room, recorded in MP3 audio using Sony Ericsson, Model K79, São Paulo, Brazil. The average duration of the phonological awareness application test was 40 minutes, ${ }^{21}$ and average duration for the AMLR (Auditory Middle Latency Response) test was 20 minutes; both were performed in a single session. To record the AMLR, right and left ears were stimulated and electrodes were placed on the right and left hemispheres.

The students were positioned in a recliner and instructed to remain with their eyes open and alert. The exam environment was protected acoustically and electrically. The electrodes were fixed with microporous tape after cleaning the skin with abrasive paste. Electrolytic paste was used to improve the conductivity. The impedance of each electrode did not exceed $5 \mathrm{k} \Omega$, and impedance between the electrodes did not exceed $2 \mathrm{k} \Omega .^{22}$

For data collection, the electrodes were placed at $\mathrm{C} 3$ and $\mathrm{C} 4$ (left and right hemisphere), in reference to the ears A1 and A2 
(left and right ear), ipsilateral and contralateral matched, and ground at Fz (forehead). As stimuli, rarefaction monaural filtered clicks at $80-\mathrm{dB}$ hearing level were used, with presentation rate of 11 stimuli per second, analysis time (window) of 100 milliseconds, acoustic filter of 10 to $100 \mathrm{~Hz}$, and sensitivity of $75 \mu \mathrm{V}$.

Results were interpreted based on the latency of $\mathrm{Na}$ and $\mathrm{Pa}$ waves and Na-Pa amplitude, parameters that were classified into normal or abnormal (prolonged) according to the normality recommended in the literature, which states that in normal conditions, $\mathrm{Na}$ appears as the first highest negative peak between 12 and 27 milliseconds; followed by Pa, which is the highest positive peak after $\mathrm{Na}$, between 25 and 35 milliseconds; and then Na-Pa amplitude, with approximate value of $1.0 \mu \mathrm{V} .^{22}$

Statistical analysis was performed using the Statistica 7.0 software, São Paulo, Brazil. We first performed descriptive statistics (mean, confidence intervals, and standard deviation), then verified data normality using the Shapiro-Wilk test, identifying the study variables as nonparametric.

To analyze the correlation between measures of MLR and phonological awareness, we used the coefficient of linear Spearman correlation, which can vary between -1 and +1 . A value of -1 is a perfect negative correlation and the value +1 is a perfect positive correlation. The value of 0 represents no correlation. The significance level was $\leq 0.05$.

\section{Results}

The results of the phonological awareness test-CONFIAS, including the scores on the subtests of syllabic and phonemic awareness, are presented in -Table 2.

- Table 3 shows the descriptive statistics (mean, confidence interval, and standard deviation) of the AMLR measurements and combinations of ear and hemisphere in relation to the variables $\mathrm{Na}$ latency, Pa latency, $\mathrm{Nb}$ latency, and $\mathrm{Nb}$ and NaPa amplitude.

- Table 4 shows the correlation measure between the results of phonological awareness and AMLR tests according to ear and hemisphere. Measurements of the Spearman correlation coefficient negative showed weak to moderate correlation, indicating that with increased scores of the phonological awareness subtests, the latency values of $\mathrm{Na}$, $\mathrm{Pa}$, and $\mathrm{Nb}$ waves decreased in both ears and hemispheres, especially those obtained via the contralateral ascending right ear left hemisphere and left ear right hemisphere.

A negative moderate correlation was observed in the $\mathrm{Pa}$ component and syllabic phonological awareness. Results are presented in -Fig. 1. The opposite effect was found for amplitude Na-Pa measures, where a weak positive correlation was observed, indicating that the phonological awareness scores increased as Na-Pa amplitude also increased.

\section{Discussion}

The altered phonological awareness abilities result from difficulty in cognitive mechanisms to analyze, synthesize, manipulate, store, and recall linguistic information. ${ }^{11,23}$ Such changes were identified in the sample of this study, revealing that students with learning disabilities and average age of 9 years and 9 months showed low scores for the age group in phonological awareness subtests, specifically in phonemic awareness. ${ }^{18,20,21}$ The phonological awareness abilities and auditory processing have been investigated in students with learning disorders, and these studies have revealed the relationship between low performance, both in phonological awareness and auditory processing. ${ }^{7,8,11,19,24}$

Studies investigating phonological awareness abilities associated with auditory abilities in students with dyslexia and learning disorders revealed that coding and organization of acoustic spectra impairments may be responsible for changes in metalinguistic abilities observed in this population. ${ }^{7,9,19}$ The deficits in information auditory processing have been studied in populations of children with learning disorders, and $\sim 80 \%$ of students with complaints related to reading and/ or writing also present auditory processing alterations, which often interfere with the acquisition of reading and writing. ${ }^{23}$

The AMLR examination revealed, from the descriptive statistics in - Table 3, that the prolonged Pa latency in the contralateral pathway in children with learning disorders does not reach values higher than $30 \mathrm{~ms}$ in Pa latency in pediatric populations with typical development. ${ }^{10,13,25}$ The neural origin of the Pa wave is attributed to the medial area of Heschl gyrus, ${ }^{26}$ which is responsible for acoustic recognition and discrimination abilities of the auditory cortex. ${ }^{27}$ In this study, when the correlation between the Pa component and the syllabic awareness was performed, there was an association between AMLR and phonological awareness in students with learning disorders, confirming the relationship between auditory and phonological abilities. Thus, the operation of the ascending auditory pathways is essential for decoding sound information because any changes affect the phonemic structure and auditory-linguistic association in the primary auditory cortical area as in the case of students with learning disabilities. $^{28}$

Recognition and manipulation of syllabic structure during the syllabic awareness tests are not only based on the acoustic-perceptual characteristics of intensity and duration of the syllable. Speech perception can also be understood as an extralinguistic system of the auditory system related to the symbolic and abstract phenomenon of cognition. ${ }^{29}$ During the syllabic awareness tests, structures are recognized from the lexical knowledge that recalls their meaning through previous linguistic experiences, ${ }^{29}$ which could explain the better performance of students in this study of syllabic tasks.

The CANS is a net composed of innumerous nerve fibers, and the majority of these fibers cross and uncross this system at some point. Thus, the left auditory cortex is dominant for the perception of linguistic stimuli, and the right auditory cortex is more functional for the perception of tonal sounds. Such interpretation justifies the fact that a specific association has been observed between syllabic awareness and AMLR (Pa wave) in students with learning disorders stimulated with nonverbal sounds in this study.

The opposite effect was observed for Na-Pa amplitude measures, where a positive weak correlation was found. 
Table 2 Distribution of participants as for CONFIAS score in syllabic and phonemic subtests

\begin{tabular}{|c|c|c|c|c|}
\hline \multirow[t]{2}{*}{ CONFIAS } & \multicolumn{4}{|c|}{ Research group $(n=25)$} \\
\hline & Mean score & Standard deviation & Minimum & Maximum \\
\hline Subtests syllabic & 28.64 & 6.06 & 16.00 & 38.00 \\
\hline Subtests phonemic & 17.16 & 6.47 & 6.00 & 28.00 \\
\hline
\end{tabular}

Abbreviation: CONFIAS, phonological awareness sequential evaluation instrument.

The local electrical activity measurement of these components, described in microvolts, results from the auditory stimulation of the primary auditory cortex and secondary areas involved in linguistic processing and tends to be reduced in patients with learning disorders ${ }^{30}$; these values may increase as auditory performance and phonological awareness improve.

Further studies with different methodologies should be conducted, such as case-control studies and randomized clinical trials, to help understand the findings in this study (i.e., whether the findings constitute specific manifestations of students with learning disorders or whether linguistic or educational environment may influence directly or indirectly on the occurrence of such events observed in this study). Further studies that address assessment and intervention to analyze the variation of AMLR measures concerning decrease in latency and increase in amplitude of students' waves may favor the observation of the relationship between the measures and confirm the positive effect of simultaneous interventions under hearing and phonological awareness, thus reducing the risks of generic interpretations and possible limitations found in this study.

\section{Conclusion}

This study allowed a better characterization of AMLRs and phonological awareness tests in children with learning disabilities and allowed us to understand the correlation between the tests in the study group. When phonological awareness subtests were performed, specifically the phonemic awareness tests, the

Table 3 AMLR Statistics according to ear and hemisphere

\begin{tabular}{|c|c|c|c|c|c|c|}
\hline \multirow[t]{2}{*}{ Ear } & \multirow[t]{2}{*}{ Hemisphere } & \multirow[t]{2}{*}{ Variable } & \multirow[t]{2}{*}{ Mean } & \multicolumn{2}{|c|}{ Mean 95\% Cl } & \multirow[t]{2}{*}{ Standard deviation } \\
\hline & & & & LL & UL & \\
\hline \multirow[t]{10}{*}{ Right } & \multirow[t]{5}{*}{ Right } & lat_na & 19.16 & 17.73 & 20.58 & 3.45 \\
\hline & & lat_pa & 35.29 & 32.67 & 37.92 & 6.36 \\
\hline & & lat_nb & 49.31 & 46.3 & 52.32 & 7.3 \\
\hline & & Ampl_Na_Pa & 1.36 & 1.13 & 1.6 & 0.56 \\
\hline & & age & 9.92 & 9.15 & 10.69 & 1.87 \\
\hline & \multirow[t]{5}{*}{ Left } & lat_na & 19.1 & 17.75 & 20.45 & 3.27 \\
\hline & & lat_pa & 35.35 & 32.91 & 37.79 & 5.91 \\
\hline & & lat_nb & 50.40 & 47.59 & 53.31 & 6.93 \\
\hline & & Ampl_Na_Pa & 1.55 & 1.02 & 2.09 & 1.29 \\
\hline & & age & 9.92 & 9.15 & 10.69 & 1.87 \\
\hline \multirow[t]{10}{*}{ Left } & \multirow[t]{5}{*}{ Right } & lat_na & 20.7 & 18.83 & 22.57 & 4.53 \\
\hline & & lat_pa & 35.42 & 32.45 & 38.39 & 7.19 \\
\hline & & lat_nb & 49.34 & 45.92 & 52.77 & 8.31 \\
\hline & & Ampl_Na_Pa & 1.52 & 1.18 & 1.86 & 0.83 \\
\hline & & age & 9.92 & 9.15 & 10.69 & 1.87 \\
\hline & \multirow[t]{5}{*}{ Left } & lat_na & 19.9 & 18.25 & 21.55 & 3.99 \\
\hline & & lat_pa & 34.46 & 31.84 & 37.07 & 6.33 \\
\hline & & lat_nb & 49.69 & 46.53 & 52.85 & 7.65 \\
\hline & & Ampl_Na_Pa & 1.25 & 0.9 & 1.59 & 0.84 \\
\hline & & age & 9.92 & 9.15 & 10.69 & 1.87 \\
\hline
\end{tabular}

Abbreviations: Ampl_, amplitude; CI, confidence interval; lat_, latency; LL, lower limit; AMLR, auditory middle latency response; UL, upper limit. 
Table 4 Spearman correlation ( $R$ ) between the CONFIAS and AMLR subtests according to ear (right and left) and hemisphere (right and left)

\begin{tabular}{|l|l|l|l|l|l|l|l|l|}
\hline \multirow{2}{*}{ CONFIAS } & \multicolumn{4}{l}{ Right hemisphere } & \multicolumn{4}{l|}{ Left hemisphere } \\
\cline { 2 - 9 } & Na & Pa & Nb & Amp Na-Pa & Na & Pa & Nb & Amp Na-Pa \\
\hline Right ear & & & & & & & & \\
\hline Syllabic & -0.27 & $-0.42^{\mathrm{a}}$ & -0.02 & 0.14 & -0.22 & $-0.61^{\mathrm{a}}$ & -0.28 & -0.30 \\
\hline Phonemic & -0.08 & -0.27 & 0.19 & 0.21 & -0.16 & -0.26 & -0.05 & 0.24 \\
\hline Left ear & & & & & & & & \\
\hline Syllabic & $-0.54^{\mathrm{a}}$ & $-0.52^{\mathrm{a}}$ & -0.25 & $0.49^{\mathrm{a}}$ & $-0.58^{\mathrm{a}}$ & $-0.45^{\mathrm{a}}$ & -0.03 & $0.40^{\mathrm{a}}$ \\
\hline Phonemic & -0.35 & -0.24 & 0.05 & 0.32 & -0.07 & 0.12 & 0.26 & 0.38 \\
\hline
\end{tabular}

Abbreviations: Amp, amplitude; CONFIAS, phonological awareness sequential evaluation instrumentl; AMLR, auditory middle latency response. ${ }^{\mathrm{a}} \mathrm{p}<005$.
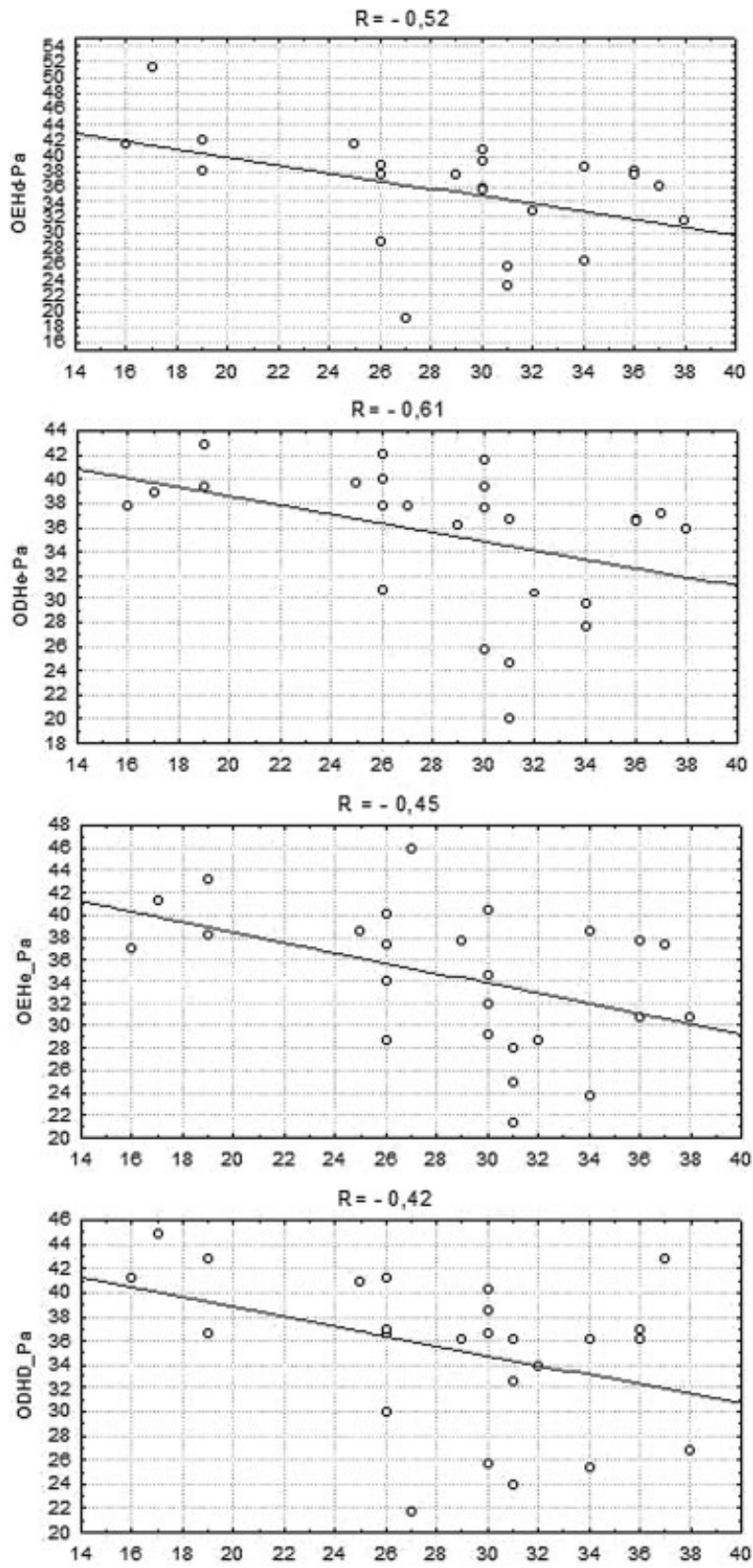

Fig. 1 Pa component and syllabic phonological awareness. Abbreviations: RE, right ear; LE, left ear; RH, right hemisphere; $L H$, left hemisphere. students showed a low score for the age group. Prolonged Pa latency was observed in contralateral pathway in the AMLR test.

In the correlation between the measurements, we observed a weak to moderate negative correlation for the latency of wave $\mathrm{Pa}$ and a weak positive correlation for the $\mathrm{Na}$-Pa amplitude, which may indicate a relationship between the measures and confirm the positive effect of simultaneous interventions under hearing and phonological awareness.

Thus, this study showed that auditory and metaphonological training can provide changes in the neurophysiological response in the auditory pathway, and consequently in results for AMLR and phonological abilities.

\section{References}

1 Berninger VW, Nielsen KH, Abbott RD, Wijsman E, Raskind W. Writing problems in developmental dyslexia: under-recognized and under-treated. J Sch Psychol 2008;46(1):1-21

2 Castles A, Coltheart M, Wilson K, Valpied J, Wedgwood J. The genesis of reading ability: what helps children learn lettersound correspondences? J Exp Child Psychol 2009;104(1): 68-88

3 Roman AA, Kirby JR, Parrila RK, Wade-Woolley L, Deacon SH. Toward a comprehensive view of the skills involved in word reading in grades 4, 6, and 8. J Exp Child Psychol 2009;102(1): 96-113

4 Pestun MSV. Consciência fonológica no inícioda escolarização e o desempenho ulterior em leitura e escrita: estudo correlacional. Estud Psicol 2005;10(3):407-412

5 Gindri G, Keske-Soares M, Mota HB. Memória de trabalho, consciência fonológica e hipótese de escrita. Pró-Fono Rev At Ci 2007; 19(3):313-322

6 Carvalho MAI, Alvarez AMR. Aquisição da lingua-gem escrita: aspectos da consciência fonológica. Fono Atual 2000;3(11):28-31

7 Germano GO, et al. Relação entre achados em neuroimagem, habilidades auditivas e metafonológicas em escolares com dislexia do desenvolvimento. Rev Soc Bras Fonoaudiol 2009;14(3):315-322

8 Quintas VG, Attoni TM, Keske-Soares M, Mezzomo CL. Processamento auditivo e consciência fonológica em crianças com aquisição de fala normal e desviante. Pró-Fono Rev At Ci 2010;22(4): 497-502

9 Pinheiro FH, Oliveira AM, Cardoso ACV, Capellini AS. Testes de escuta dicótica em escolares com distúrbio de aprendizagem. Braz J Otorhinolaryngol 2010;76(2):257-262

10 Arehole S, Augustine LE, Simhadri R. Middle latency response in children with learning disabilities: preliminary findings. J Commun Disord 1995;28(1):21-38 
11 Idiazábal-Aletxa MA, Saperas-Rodríguez M. Procesamiento auditivo em el transtorno específico del lenguaje. Rev Neurol 2008; 46(1):91-95

12 Schochat E, et al. Processamento auditivo: comparação entre potenciais evocados auditivos de média latência e testes de padrões temporais. Rev Cefac 2009;11(2):314-322

13 Purdy SC, Kelly AS, Davies MG. Auditory brainstem response, middle latency response, and late cortical evoked potentials in children with learning disabilities. J Am Acad Audiol 2002;13(7):367-382

14 Lishman WA. Developmental dyslexia. J Neurol Neurosurg Psychiatry 2003;74(12):1603-1605

15 Salles JF, Mota HB, Cechella C, Parente MAMP. Desenvolvimento da consciência fonológica de crianças de primeira e segunda séries. Pro Fono 1999;11(2):68-76

16 Wechsler D (ed.). WISC III: Escala de Inteligência Wechsler para Crianças: Manual (3rd ed). São Paulo: Casa do Psicólogo; 2002

17 Tabaquim MLM. Validação do Exame Neuropsicológico e análise das funções corticais superiores em crianças do ensino fundamental [thesis]. Faculdade de Ciências Médicas Unicamp, Campinas; 2008

18 Capellini AS, Toyota P, Santos LCA, Lourencetti MD, Padula NAMR. Caracterização do desempenho fonológico, da leitura e da escrita de escolares com dislexia e distúrbio de aprendizagem. Caderno de Filosofia e Educação 2007;9:37-70

19 Oliveira AM, Cardoso ACV, Capellini AS. Desempenho de escolares com distúrbio de aprendizagem e dislexia em testes de processamento auditivo. Rev Cefac 2011;13(3):513-521

20 Moojen S, Lamprecht R, Santos R, et al. CONFIAS: Consciência fonológica: instrumento de avaliação sequencial. São Paulo, Brazil: Casa do Psicólogo; 2003:38
21 Rizzon GF, Chiechelshi P, Gomes E. Relação entre consciência fonológica e desvio fonológico em crianças da $1^{\text {a }}$ série do ensino fundamental. Rev Cefac 2009;11(2):201-207

22 Hall J. Handbook of Auditory Evoked Responses. Boston, MA: Allyn \& Bacon; 2006

23 Margalli SAC. A função auditiva na terapia dos distúrbios de leitura e escrita. In: Santos MTM, Navas ALG, eds. Distúrbio de Leitura e Escrita: teoria e prática. São Paulo, Brazil: Manole; 2002:263-328

24 Silver CH, Ruff RM, Iverson GL, et al; NAN Policy and Planning Committee. Learning disabilities: the need for neuropsychological evaluation. Arch Clin Neuropsychol 2008;23(2):217-219

25 Frizzo ACF, et al. Auditory middle latency response in children with learning difficulties. Int Arch Otorhinolaryngol 2012; 3:335-340

26 Yvert B, Crouzeix A, Bertrand O, Seither-Preisler A, Pantev C. Multiple supratemporal sources of magnetic and electric auditory evoked middle latency components in humans. Cereb Cortex 2001;11(5):411-423

27 Kraus N, McGee T. The middle latency response generating system. Electroencephalogr Clin Neurophysiol Suppl 1995; 44:93-101

28 Veuillet E, Magnan A, Ecalle J, Thai-Van H, Collet L. Auditory processing disorder in children with reading disabilities: effect of audiovisual training. Brain 2007;130(Pt 11):2915-2928

29 Bybee J. Phonology and Language Use Cambridge Studies in Linguistics. Cambridge, UK: Cambridge University Press; 2001

30 Sauer L, et al. Processamento auditivo e Spect em crianças com dislexia. Arch Neuropsiq 2006;64(1):108-111 